
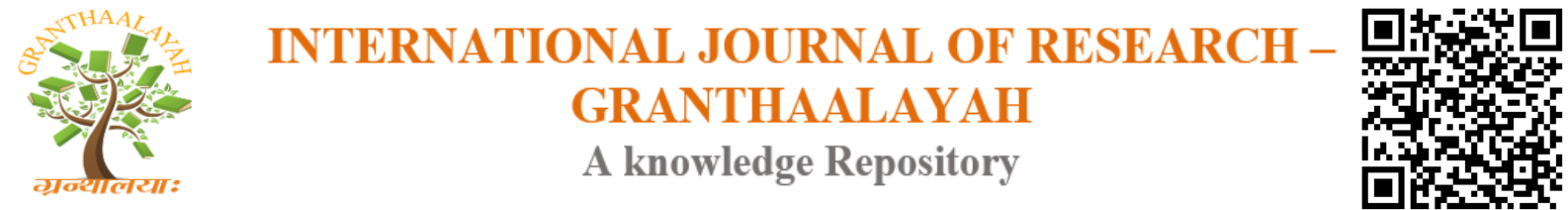

Science

\title{
REVIEW OF NEONATAL JAUNDICE AND ITS MANAGEMENT
}

\author{
Dr. Pooja Pattanshetti ${ }^{1}$, Dr. P. K. Dash ${ }^{2}$ \\ ${ }^{1}$ P.G. Scholar, Department of Koumarbhritya, Y.A.C.P.G.T \& R.C, Kodoli, Kolhapur, India \\ ${ }^{2}$ Guide, Professor, Department of Koumarbhritya, Y.A.C.P.G.T \& R.C, Kodoli, Kolhapur, India
}

\begin{abstract}
Jaundice is the most common finding during neonatal period. It is observed during the 1st week of life in approximately $60 \%$ of term infant and $80 \%$ of preterm infants. Level of serum bilirubin is not raised that much so as to cause fatal brain damage. It is the most common disease during neonatal period occurring mostly due to increased hemolysis, decreased hepatic clearance, enterohepatic circulation, immaturity, blood group incompatibility and infections. Its management includes 1] Phototherepy 2] Exchange transfusion are two major effective therapeutic modalities available today. Additional options include Pharmacotherapy in the form of phenobarbital and high dose intravenous immunoglobulin.
\end{abstract}

Keywords: Icturusneonatorum; Serum Bilirubin; Phototherapy.

Cite This Article: Dr. Pooja Pattanshetti, and Dr. P. K. Dash. (2018). "REVIEW OF NEONATAL JAUNDICE AND ITS MANAGEMENT." International Journal of Research - Granthaalayah, 6(1), 172-176. https://doi.org/10.29121/granthaalayah.v6.i1.2018.1606.

\section{Introduction}

Jaundice is an important problem in the $1^{\text {st }}$ week of life. It is the yellow discolouration of the skin and sclera due to raised serum bilirubin. Yellow colour usually results from the accumulation of unconjugated, nonpolar, lipid-soluble bilirubin pigment in the skin. High bilirubin levels may be toxic to the developing central nervous system and may cause neurological impairment even in term newborns. Nearly $60 \%$ of terms new born become visibly jaundiced in the $1^{\text {st }}$ week of life. In the most cases, it is benign and no intervention is required. Approximately $5-10 \%$ of them have clinically significant jaundice mandating the use of phototherapy or other therapeutic options.

1] Why jaundice is more prevalent during newborn period?

If we assess neonatal jaundice according to adult parameter of jaundice estimation, it seems that most neonates get jaundiced. It is due to physiological polycythemia, shorter lifespan of fatal RBC, limited hepatic uptake, conjugation and excretion of receptor proteins and UDPGT enzyme in new born especially in premature. It is also due to paucity of bacterial flora in the gut and over 
activity of beta-glucuronidaseenzyme in the newborn. So the increased bilirubin production, reduced hepatic clearance and enhanced entrohepatic circulation are the sole cause of increased prevalence of jaundice in newborn.

\section{Physiological Jaundice (Icturus Neonatorum)}

Under normal circumstance the level of indirect bilirubin in umbilical cord serum is $1-3 \mathrm{mg} / \mathrm{dl}$ and rises at a rate of $<5 \mathrm{mg} / \mathrm{dl} / 24 \mathrm{hr}$; thus, jaundice becomes visible on the $2^{\text {nd }}$ or $3^{\text {rd }}$ day, usually peaking between the $2^{\text {nd }}$ and $4^{\text {th }}$ days at $5-6 \mathrm{mg} / \mathrm{dl}$ and decreasing to $<2 \mathrm{mg} / \mathrm{dl}$ between the $5^{\text {th }}$ and $7^{\text {th }}$ days of life. Jaundice associated with these changes is designated physiologic and is believed to the result of increased bilirubin production from breakdown of fetal red blood cells combined with transient limitation in the conjugation of bilirubin by the immature neonatal liver.

Physiologic jaundice:-

\section{Term}

1) Incidence $50 \%$.

2) Maximum intensity on $4^{\text {th }}-5^{\text {th }}$ day of life.

3) Sr.bilirubin may not exceed $15 \mathrm{mg} / \mathrm{dl}$.

4) Disappears by $10^{\text {th }}$ day of life.

Preterm

1) Incidence $70-75 \%$.

2) Maximum on $6^{\text {th }}$ to $7^{\text {th }}$ day.

3) Sr.bilirubin may go upto $15 \mathrm{mg} / \mathrm{dl}$.

4) May persist up to $14^{\text {th }}$ days.

\section{Etiological Considration}

I. Classification based on the time of onset

Important causes of neonatal jaundice based on age of onset

$1^{\text {st }}$ day

1) Rh and $\mathrm{ABO}$ incompatibilities( haemolytic disease)

2) Intrauterine infection like toxoplasmosis

3) G-6-PD deficiency

4) Drug administration to mother( vit k etc)

2nd $\& 3^{\text {rd }}$ day

1) Physiologic

2) Hyperbilirubinemia of newborn

3) Birth asphyxia

4) Cepalohematoma

5) Acidosis

6) Hypothermia

7) Hypoglycemia 
$4^{\text {th }}$ to $7^{\text {th }}$ day

1) Septicemia

2) Syphilis

3) Toxoplasmosis

4) Cytomegalic inclusion disease

5) Breast-milk jaundice

After $1^{\text {st }}$ week

1) Septicemia

2) Extrahepatic atresia of bile duct

3) Hereditary spherocytosis

4) Neonatal hepatitis

5) Drug induced haemolytic anemia

Persistent jaundice during $1^{\text {st }}$ month

1) Inspissated bile syndrome

2) Cretinism

3) Congenital hypertropicplyroric stenosis

II. Classification based on conjugation of bilirubin

Conjugated hyperbilirubinemia which is usually secondry to Hypertrophic biliary atresia or Neonatal hepatitis in newborn.Causes of unconjugated hyperbilirubinemia Hemolytic disease of newborn:

- $\mathrm{Rh}$ isoimmunisation, $\mathrm{ABO}$ incompatibility

- Minor blood group incompatibility

Hereditary spherocytosis

Nonspherocytic haemolyticanemia:

- G-6-PD deficiency, alpha-thalassemia

Acquired hemolysis disorders:

- Vit $\mathrm{k}$ - induced hemolysis

- Microangiopathies

- Septicemia

Increased enterohepatic circulation:

- Intestinal obstruction

- Congenital hypertropic pyloric stenosis

- Meconium ileus, paralytic ileus

Decreased clearance of bilirubin:

- Inborn errors of metabolism: familial nonhemolytic jaundice

- Medication - vit k3

- Hormones: Breast milk jaundice, hypothyroidism, hypopituitarism. 


\section{Clinical Approach}

1) Is newborn term or preterm?

Basic pathology of jaundice is same in term and preterm neonates but babies at lower gestation are at a higher risk of developing brain damage at lower levels.

2) Is there in hemolysis?

- Setting of Rh or ABO incompatibility

- Onset of jaundice within $24 \mathrm{hrs}$

- Presence of pallor

- Hepatosplenomegaly

- Presence of hemolysis on the peripheral blood smear

- Raised reticulocyte count (>8\%)

- Rapid rise of bilirubin count ( $>5 \mathrm{mg} / \mathrm{dl}$ in $24 \mathrm{hrs})$ shouldraise a suspicion of haemolytic jaundice.

3) Is the baby otherwise sick (sepsis, asphyxia or healthy)?

- Presence of lethargy

- Poor feeding, failure to thrive

- Hepatosplenomegaly

- Temp.instablity or apnea

- May be marker of an underlying serious disease.

4) Dose the infant have cholestatic jaundice?

- Presence of dark yellow urine or pale coloured stools would suggest cholestatic jaundice.

5) Dose the baby have any bilirubin-induced brain dysfunction (kernicterus)?

These include presence of

- Lethargy

- Poor feeding

- Hypotonia

Advanced sings:-

- Seizures

- Retrocollis

- Paralysis of upward gaze

- Shrill cry.

\section{Laboratry Investigation}

1) Sr.bilirubin, both direct and indirect.

2) ABP and Rh blood grouping of mother as well as baby

3) Hemoglobin/peripheral smear

4) Reticulocyte count

5) Coobs test of mother as well as baby 
6) Blood culture

7) Liver function tests

8) G-6-PD enzyme studies

\section{Management}

Principles of management

Currently, phototherapy and exchange transfusion are two major effective therapeutic modalities available toady. Additional options include pharmacotherapy in the form of phenobarbital etc.

\begin{tabular}{|l|c|c|c|c|}
\hline \multirow{2}{*}{ Birth weight } & \multicolumn{3}{|c|}{ Guideline for management of Neonatal Jaundice } \\
\cline { 2 - 5 } & \multicolumn{2}{|c|}{ Total serum bilirubin (mg/dl) } \\
\cline { 2 - 5 } & Phototherapy & $\begin{array}{c}\text { Exchange } \\
\text { Transfusion }\end{array}$ & Phototherapy & $\begin{array}{c}\text { Exchange } \\
\text { Transfusion }\end{array}$ \\
\hline <1000gm & $5-7$ & $11-13$ & $4-6$ & $10-12$ \\
\hline $1001-1500 \mathrm{gm}$ & $7-10$ & $13-15$ & $6-8$ & $11-13$ \\
\hline $1501-2000 \mathrm{gm}$ & $10-12$ & $15-18$ & $8-10$ & $13-15$ \\
\hline $2001-2500 \mathrm{gm}$ & $12-15$ & $18-20$ & $10-12$ & $15-18$ \\
\hline
\end{tabular}

